\title{
Behzad Mofidi-Nasrabadi. "The Gravity of New City Formations: change in Settlement Patterns Caused by the foundation of Gondishapur and Eyvan-e Karkheh"
}

\section{Domiziana Rossi}

\section{(2) OpenEdition}

\section{Journals}

Electronic version

URL: https://journals.openedition.org/abstractairanica/53185

DOI: $10.4000 / a b s t r a c t a i r a n i c a .53185$

ISSN: 1961-960X

Publisher:

CNRS (UMR 7528 Mondes iraniens et indiens), Éditions de l'IFRI

Electronic reference

Domiziana Rossi, "Behzad Mofidi-Nasrabadi. "The Gravity of New City Formations: change in Settlement Patterns Caused by the foundation of Gondishapur and Eyvan-e Karkheh"', Abstracta Iranica [Online], Volume 42-43 | 2021, document 37, Online since 30 December 2021, connection on 04 January 2023. URL: http://journals.openedition.org/abstractairanica/53185 ; DOI: https://doi.org/ 10.4000/abstractairanica.53185

This text was automatically generated on 4 January 2023.

All rights reserved 


\title{
Behzad Mofidi-Nasrabadi. "The Gravity of New City Formations: change in Settlement Patterns Caused by the foundation of Gondishapur and Eyvan-e Karkheh"
}

\author{
Domiziana Rossi
}

\section{REFERENCES}

Behzad Mofidi-Nasrabadi. "The Gravity of New City Formations: change in Settlement Patterns Caused by the foundation of Gondishapur and Eyvan-e Karkheh" in Yousef Moradi (ed.). Afarin Nameh. Essays on the Archaeology of Iran in Honour of Mehdi Rahbar. Tehran: The Research Institute of Cultural Heritage and Tourism (RICHT), 2019, p. 101-110.

1 At the start of the paper, Mofidi-Nasrabadi correctly points out the lack of information on cities of Susiana, such as Gondishapur and Eyvan-e Karkheh. After a summarized and useful overview of the textual mentions of Gondishapur, Mofidi-Nasrabadi proceeds in a re-evaluation of the archaeological data. The first premise to this methodological approach is that the urbanisation process of a new city results in the depopulation of the surrounding villages. The second premise is that the population fluctuation can be analysed by looking at the quantity and size of not-excavated settlements. Thus, Wenke's results of the survey carried out in the Dez River valley had been compared diachronically to prove that the number of settlements of the western and the eastern plains depended on the existence of big urban centres. Related to the presence of an important city, we notice a decrease of rural settlements on that side of the river their increase on the other side. 
2 By basing on this analysis of the variability of the settlement's quantity, it seems that also the foundation of the mysterious Eyvan-e Karkheh might be dated at the beginning of the Sasanian period. This methodological approach sheds light on a new settlement pattern which possibly points out a food supply found further away than to the immediate surroundings.

\section{AUTHORS}

DOMIZIANA ROSSI

Cardiff University 